\title{
Tissue- and Cell-Specific Alternative Splicing of NFIC
}

\author{
Ejvis Lamani ${ }^{\mathrm{a}}$ Yixin $\mathrm{Wu}^{\mathrm{a}}$ Juan Dong ${ }^{\mathrm{a}}$ Mark Stephen Litaker ${ }^{\mathrm{a}}$ \\ Ana Carolina Acevedo ${ }^{b}$ Mary MacDougalla \\ a Institute of Oral Health Research, School of Dentistry, University of Alabama at Birmingham, \\ Birmingham, Ala., USA; ${ }^{b}$ Oral Care Center for Inherited Diseases, University of Brasilia, Brasilia, Brazil
}

\author{
Key Words \\ Nuclear factor I-C • Alternative splicing • Gene structure • \\ Dental cells $\cdot$ Root formation
}

\begin{abstract}
Alternative splicing is an important mechanism for increasing genetic complexity leading to multiple transcripts from single genes and gene regulation through alternative promoters. Splicing often leads to unique tissue-specific patterns of mRNAs with specific biological functions. Nuclear factor I-C (NFI-C), a member of the NFI gene family, is expressed in numerous tissues including brain, liver, spleen and heart. However, the unique dental phenotype of $\mathrm{Nfic}^{-/-}$ mice lacking molar roots demonstrates a critical role for this transcription factor in root formation. In humans, the NFI-C gene is alternatively spliced producing 4 isoforms. However, different spliced variants have not been studied in association with tissue specificity. The main objective of this study is to identify the NFI-C isoforms expressed in dental cells/tissues, comparing them to the spliced variants in nondental cells/tissues and to analyze their relative expression levels in various cell types. Using bioinformatics, we analyzed the $\mathrm{NFI}-\mathrm{C}$ gene structure, identifying 2 potential alternative promoters driving expression of selective mRNA transcripts. Our studies show the expression of $3 \mathrm{NFI}-\mathrm{C}$ transcripts with the overall splicing pattern conserved between dental and nondental cells tested. Furthermore, by quantitative realtime PCR analysis, we found that although the relative levels
\end{abstract}

of these transcripts were similar in dental and nondental cells, significant differences were observed within the dental cells tested. These are the first studies to analyze the expression of NFI-C isoforms in dental versus nondental cells/tissues, finding subtle cell-/tissue-specific expression patterns that could explain the dental phenotype of $\mathrm{Nfic}^{-/-}$mice.

Copyright $\odot 2008$ S. Karger AG, Basel

\section{Introduction}

The nuclear factor I (NFI) family of transcription factors, first described as adenovirus DNA replication factors, is necessary for optimal cellular gene expression [Mermod et al., 1989; Gounari et al., 1990]. This gene family contains 4 members, NFIA, NFIB, NFIC and NFIX, all of which exist as multiple protein products. Analyses of each NFI gene knockout mice demonstrates the explicit

\begin{tabular}{ll} 
Abbreviations used in this paper \\
\hline cDNA & complementary DNA \\
EOE & enamel organ epithelium \\
DF & dental follicle \\
DP & dental pulp \\
NFI & nuclear factor I \\
PDL & periodontal ligament \\
RDD & radicular dentin dysplasia
\end{tabular}

\section{KARGER}

(๑) 2008 S. Karger AG, Basel

Fax +4161306 1234

E-Mail karger@karger.ch

www.karger.com
Accessible online at: www.karger.com/cto
Dr. Mary MacDougall

Institute of Oral Health Research, University of Alabama at Birmingham 1919 7th Avenue South, SDB 702

Birmingham, AL 35294-0007 (USA)

Tel. +1 205996 5122, Fax +1 205996 5109, E-Mail macdougall@uab.edu 
Table 1. Primers designed for the detection and quantification of NFI-C alternative splicing

\begin{tabular}{|c|c|c|}
\hline Primer sets & Sequences $\left(5^{\prime}\right.$ to $\left.3^{\prime}\right)$ & Expected products, bp \\
\hline PCR exon 1A & $\begin{array}{ll}\text { F: } & \text { TCCTCGCAGCAGCGCCATG } \\
\text { R: } & \text { TAGGCCAGGTAGAGGTCCAG }\end{array}$ & 534 \\
\hline PCR exon $1 \mathrm{~B}$ & $\begin{array}{ll}\text { F: } & \text { ATGACTCAGTAAGTTCAGCGC } \\
\text { R: } & \text { TAGGCCAGGTAGAGGTCCAG }\end{array}$ & 606 \\
\hline $\begin{array}{l}\text { PCR NFI-C } 1 / \mathrm{C} 2 / \mathrm{C} 4 \\
\text { NFI-C3 }\end{array}$ & $\begin{array}{ll}\text { F: } & \text { CTGGTCATGGTCATCCTGTTC } \\
\text { R: } & \text { GTTCAGGTCGTATGCCAGGT }\end{array}$ & $\begin{array}{l}390 \\
318\end{array}$ \\
\hline $\begin{array}{l}\text { PCR NFI-C1 } \\
\text { NFI-C2/C3 } \\
\text { NFI-C4 }\end{array}$ & $\begin{array}{ll}\text { F: } & \text { GCTCTGCATTTCCCTACGAC } \\
\text { R: } & \text { TTCCTGGGACGATGGAGAAG }\end{array}$ & $\begin{array}{l}456 \\
302 \\
216\end{array}$ \\
\hline qRT-PCR exon 1A & $\begin{array}{ll}\mathrm{F}: & \text { TCCTCGCAGCAGCGCCATG } \\
\mathrm{R}: & \text { TTCTTGCCGGTGATGCTCAGCA }\end{array}$ & 300 \\
\hline qRT-PCR exon 1B & $\begin{array}{ll}\text { F: } & \text { ATGACTCAGTAAGTTCAGCGC } \\
\text { R: } & \text { CCCACTTCTGCTTGACCTC }\end{array}$ & 280 \\
\hline qRT-PCR NFI-C2 & $\begin{array}{ll}\text { F: } & \text { CAGCAACCTGGACCGCCT } \\
\text { R: } & \text { TTCCTGGGACGATGGAGAAG }\end{array}$ & 161 \\
\hline qRT-PCR NFI-C4 & $\begin{array}{ll}\text { F: } & \text { CAGCAACCTGGACCGTCC } \\
\text { R: } & \text { TTCCTGGGACGATGGAGAAG }\end{array}$ & 75 \\
\hline qRT-PCR NFI-C1 & $\begin{array}{ll}\text { F: } & \text { ACCACCTCCGAGGGAGGA } \\
\text { R: } & \text { TTCCTGGGACGATGGAGAAG }\end{array}$ & 186 \\
\hline
\end{tabular}

and vital role of these proteins during mammalian development [das Neves et al., 2001; Grunder et al., 2002; SteelePerkins et al., 2003]. The NFIC gene is critical for normal root formation, since $\mathrm{Nfic}^{-/}$mice lack molar roots [SteelePerkins et al., 2003]. In humans, a similar phenotype (missing roots) is observed in patients with a condition called rootless teeth or radicular dentin dysplasia (RDD; OMIM125400). This rare inherited disorder is characterized by incomplete to absent root formation resulting in premature exfoliation of both dentitions.

The NFIC gene, located on human chromosome 19 p13.3, is currently reported as encoded by 11 exons that are alternatively spliced producing 4 protein products as recorded in Ensembl [Hubbard et al., 2007]. However, the spliced variants have not been studied in association with tissue or cell type-specific expression patterns, for example, dental versus nondental tissues or dental pulp versus periodontal ligament (PDL) cells. Furthermore, the C-terminal domain of NFI proteins is thought to act as a transcript modulator element [Kruse et al., 1994; Chaudhry et al., 1997]. This domain shows no homology among the 4 gene family members, but is highly conserved across species for each member. It has been suggested that this domain may be responsible for the distinct spatialtemporal expression of these proteins in different tissues during mouse pre- and postnatal development. In this study, we characterized the human NFIC gene structure using a bioinformatics approach in order to determine and quantify the specific NFI-C alternatively spliced mRNA transcripts expressed in nondental versus dental tissues relevant to the phenotype found in RDD.

\section{Materials and Methods}

Bioinformatics

The architecture of NFIC was analyzed using the GeneCard [Safran et al., 2003; Shmueli et al., 2003; Yanai et al., 2005] and Ensembl databases [Hubbard et al., 2007].

\section{Cell Cultures}

Explant cultures of dental tissues were established from teeth extracted from patients 13-18 years of age using established techniques [MacDougall et al., 1996]. These teeth were removed as part of the clinical treatment plan and were used with informed consent from patients. Explant cultures from crown tissues 


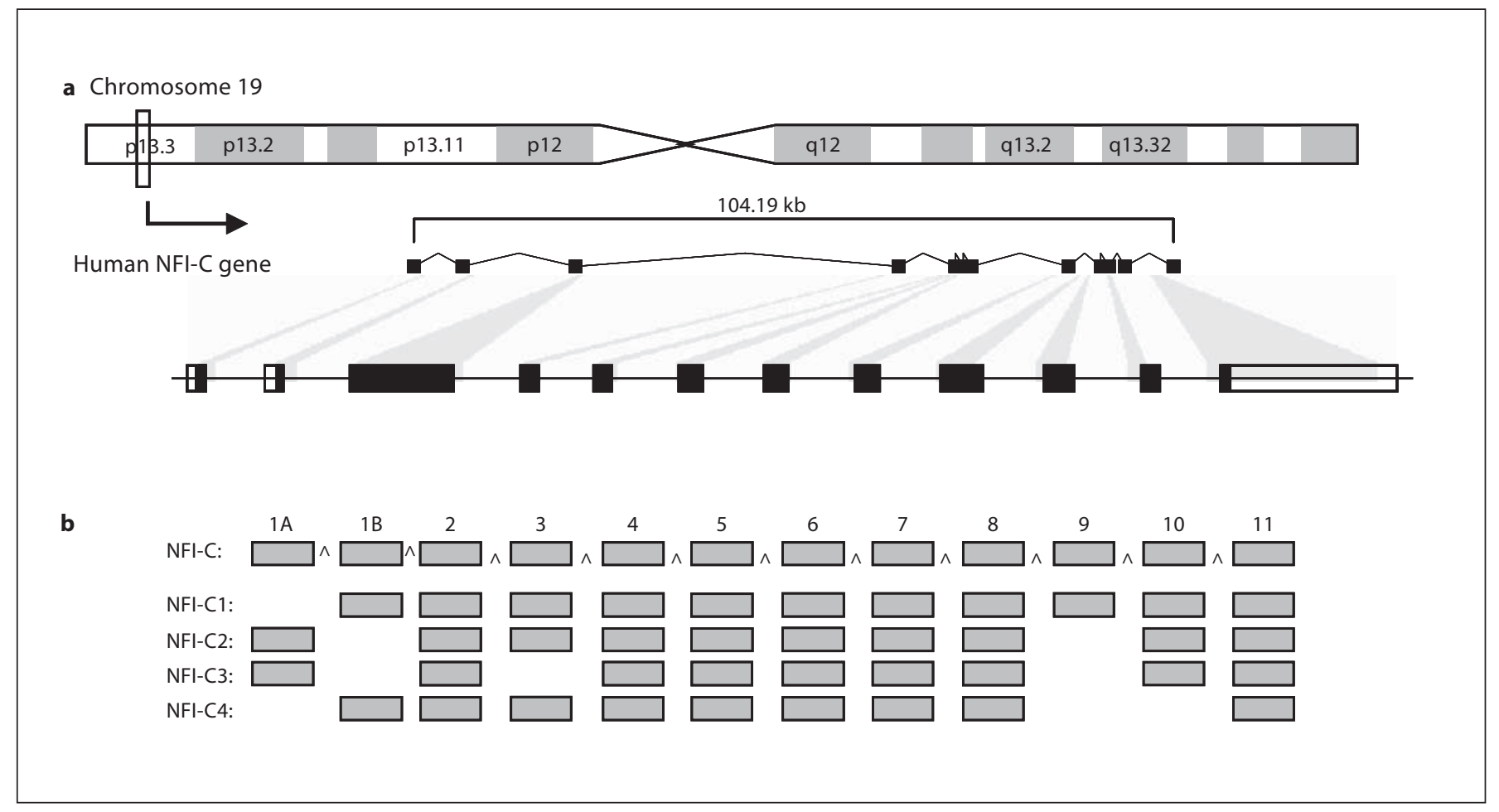

Fig. 1. Diagram of the human NFIC gene and its alternatively spliced transcripts. a Chromosomal location and overall NFIC gene structure. b The 4 spliced variants (NFI-C1 to NFI-C4) as reported by Hubbard et al. [2007].

(enamel organ epithelium and dental pulp) and root structures [PDL and dental follicle (DF)] were used to produce primary cell populations. Cell type was confirmed by gene expression profiles using tissue-specific markers. Cell populations at low passage number (2-5) were frozen back for cell stocks.

For these experiments, cell populations were grown in DMEM or $\alpha$-MEM containing $10 \% \mathrm{FBS}, 1 \%$ antibiotics at $37^{\circ} \mathrm{C}$ for 4 days until near confluence as previously described [MacDougall et al., 1996]. Hela cells, grown in DMEM/F-12 medium, were used as the nondental NFI-C-expressing positive control.

\section{Target Complementary DNAs}

RNA was isolated from the selected cells using RNA STAT- 60 (Tel-Test Inc., Friendswood, Tex., USA). The isolated RNA was converted to complementary DNA (cDNA) using random hexamers and MultiScribe reverse transcriptase (ABI TaqMan Kit; Applied Biosystems, Foster City, Calif., USA). Positive control cDNAs from brain, liver, spleen, heart and kidney (OriGene Technologies Inc., Rockville, Md., USA) were used to screen for alternatively spliced NFI-C transcripts in high level-expressing nondental tissues.

\section{Oligonucleotide Probes}

In order to amplify the various NFI-C isoforms, we designed and tested a number of $5^{\prime}$ and $3^{\prime}$ (sense and antisense) primer sets (table 1). These primers were produced using a commercial service (Invitrogen, San Diego, Calif., USA).
PCR and Quantitative Real-Time PCR Analysis

Target transcripts were amplified from various tissues during 35 cycles of PCR amplification with $1 \mathrm{U}$ of Taq polymerase (Sigma-Aldrich, St. Louis, Mo., USA) and specific primer sets (10 pM). GAPDH was used as an internal positive control for the integrity of the cDNAs and PCR reactions, while no added target cDNA (water only) was our negative control. PCR products were separated by agarose gel electrophoresis, purified and sequenced to confirm the amplification products and spliced variants.

For quantitative real-time PCR, amplification reactions were analyzed in real time on an ABI 7500 thermocycler (Applied Biosystems) using SYBR Green (Invitrogen). Reactions were run in triplicate with cDNAs from 3 independent cultures for each cell type, using specific NFI-C transcript primer sets (table 1). Transcript abundance was normalized to the GAPDH housekeeping gene and examined for significance using one-way analysis of variance with Dunnett's test.

\section{Results}

NFIC, located on human chromosome 19p13.3, is reported as being encoded by 11 exons (http://www.genecards.org/cgi-bin/carddisp.pl?gene=NFIC) [Safran et al., 2003; Shmueli et al., 2003; Yanai et al., 2005]. However, 
further analysis using the Ensembl program [Hubbard et al., 2007] identified utilization of an alternative upstream $5^{\prime}$ exon. This 68-bp exon encoding for only a single amino acid methionine was termed exon $1 \mathrm{~A}$ and we renamed the previously identified exon 1 as exon $1 \mathrm{~B}$ (fig. 1). Exon $1 \mathrm{~A}$ contains the start codon for 2 of the 4 reported NFI-C spliced variants ( $\mathrm{C} 2$ and $\mathrm{C} 3$ ), while exon $1 \mathrm{~B}$ codes for the $\mathrm{N}$ terminus of the other 2 splice variants ( $\mathrm{Cl}$ and $\mathrm{C} 4)$. We examined the expression of exons $1 \mathrm{~A}$ and $1 \mathrm{~B}$ and confirmed their presence in all tested nondental tissues (fig. 2a). Furthermore, we quantified exon $1 \mathrm{~A}$ and $1 \mathrm{~B}$ expression in dental and nondental cells and found no significant difference in the transcript levels of these exons in all cells tested (fig. 2b).

The 4 identified NFI-C isoforms are reported as NFIC1, NFI-C2, NFI-C3 and NFI-C4 (fig. 1). NFI-C1 contains a complete $\mathrm{C}$ terminus, while NFI-C2 and NFI-C3 do not express exon 9. NFI-C3 is also lacking exon 3 and NFI-C4 is missing both exons 9 and 10 . All these isoforms were previously isolated from Hela cell cDNA libraries [Santoro et al., 1988; Hubbard et al., 2007]. Interestingly,

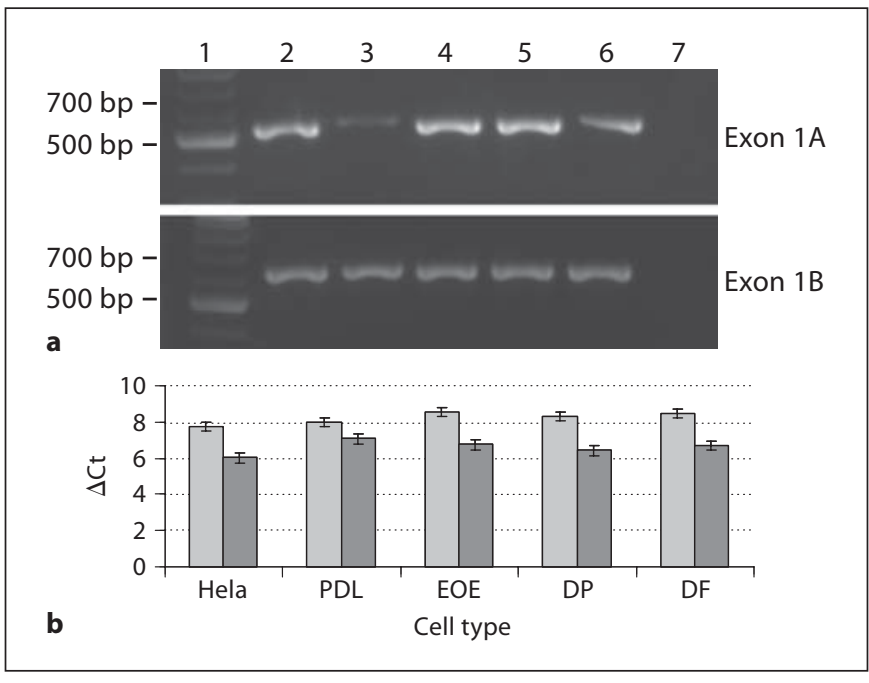

Fig. 2. Expression of NFI-C exons $1 \mathrm{~A}$ and $1 \mathrm{~B}$ in dental and nondental tissues. a Detection of exon $1 \mathrm{~A}$ and $1 \mathrm{~B}$ in kidney (2), spleen (3), brain (4), heart (5) and liver (6); DNA ladder (1) and no DNA control (7). b Quantitative real-time PCR expression levels of exon 1A (light gray) and 1B (dark gray) in Hela, PDL, enamel organ epithelium (EOE), dental pulp (DP) and DF.
Fig. 3. Alternatively spliced NFI-C transcripts in dental and nondental tissues. DNA ladder (1), exons 2-5 (2), exons 8-11 (3) and no DNA control (4).

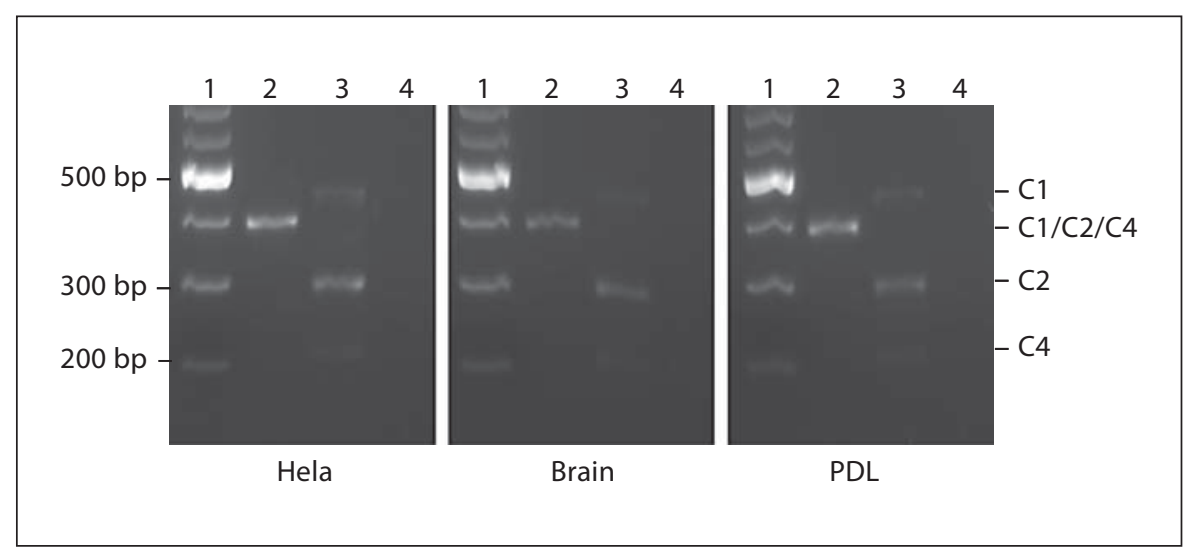

Table 2. Summary of NFI-C isoform expression profiles in dental and nondental tissues

\begin{tabular}{|c|c|c|c|c|c|c|c|c|c|c|}
\hline \multirow[t]{2}{*}{ Isoforms } & \multicolumn{6}{|c|}{ Nondental tissues } & \multicolumn{4}{|c|}{ Dental tissues } \\
\hline & brain & kidney & heart & liver & spleen & Hela & PDL & $\mathrm{EOE}$ & $\mathrm{DF}$ & $\mathrm{DP}$ \\
\hline NFI-C1 & + & + & + & + & + & + & + & + & + & + \\
\hline NFI-C2 & +++ & +++ & +++ & +++ & +++ & +++ & +++ & +++ & +++ & +++ \\
\hline NFI-C3 & - & - & - & - & - & - & - & - & - & - \\
\hline NFI-C4 & ++ & ++ & ++ & ++ & ++ & ++ & ++ & ++ & ++ & ++ \\
\hline
\end{tabular}

$\mathrm{EOE}=$ Enamel organ epithelium; DP = dental pulp; $-=$ no expression;,,$++++++=$ relative expression levels low to high. 


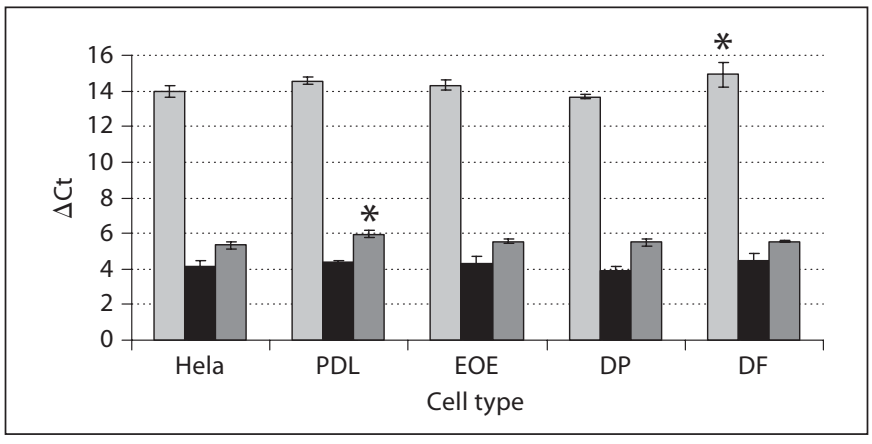

Fig. 4. Quantitative analysis of NFI-C isoforms in dental and nondental cells. NFI-C1 (light gray), NFI-C2 (black) and NFI-C4 (dark gray) transcripts were measured using $\Delta \mathrm{Ct}$ which is inversely related to the transcript levels. ${ }^{*}$ Significant differences of NFI$\mathrm{C} 1$ in DF $(\mathrm{p}=0.043)$ and NFI-C4 in PDL $(\mathrm{p}=0.0042)$ compared to respective isoform expression in Hela cells. $\mathrm{EOE}=$ Enamel organ epithelium; DP = dental pulp.

we were only able to amplify 3 of these transcripts (NFI-C1, NFI-C2 and NFI-C4) from all cell populations (fig. 3). The NFI-C3 variant was not amplified from our Hela cell cDNA under our experimental conditions. We found the same expression pattern (no NFI-C3) in brain, liver, kidney, spleen and heart. These tissues have been previously shown by microarray analysis to express higher levels of NFI-C (http://www.genecards.org/cgi-bin/ carddisp.pl?gene=NFIC) [Safran et al., 2003; Shmueli et al., 2003; Yanai et al., 2005] than the other tissues tested (table 2, fig. 3). NFI-C1, NFI-C2 and NFI-C4 were also the only transcripts confirmed in the dental cells we examined (table 2, fig. 3). Our data showed that NFI-C2 is the major isoform expressed followed by NFI-C4, with the least abundant transcript being NFI-C1. We confirmed these results by quantitative real-time PCR analysis of the NFI-C variants in dental and nondental cells. To ensure amplification of single products, our forward primers aligned at the $3^{\prime}$ end of the exon upstream of the splice junction and expended through the junction to the first 3 nucleotides of the exon downstream of the splice junction. Using one-way analysis of variance with Dunnett's test, we found a significant increase in the $\Delta \mathrm{Ct}$ of 2 isoforms: NFI-C1 in DF ( $\mathrm{p}=0.043)$ and NFI-C4 in PDL ( $\mathrm{p}=0.0042)$ compared to Hela cells (fig. 4). This increase in the $\Delta \mathrm{Ct}$ reflects a decrease in the level of these NFI-C transcripts. No significant differences were found in any of the other cell types tested. However, the general trend was lower levels of $\mathrm{C} 1$ and $\mathrm{C} 4$ transcripts in dental cell types directly involved in root formation (DF and PDL).

\section{Discussion}

Analysis of the genomic organization of human NFIC revealed an additional $5^{\prime}$ exon, making the total number of exons 12. The 2 upstream exons, $1 \mathrm{~A}$ and $1 \mathrm{~B}$, are each preferentially used for 2 alternatively spliced transcripts, $\mathrm{C} 2 / \mathrm{C} 3$ and $\mathrm{C} 1 / \mathrm{C} 4$, respectively. This suggests these 2 groups of transcripts may be under the control of different promoters. However, there were no significant differences in their expressions in the dental and nondental tissues tested, suggesting no tissue-specific use of one promoter over the other.

Prior studies [Santoro et al., 1988; Hubbard et al., 2007] have reported 4 NFI-C isoforms expressed in Hela cells by cDNA cloning. In our studies we were not able to amplify the NFI-C3 variant in Hela cells or any other cell type tested even when multiple primer sets were designed. This may be due to the very low abundance of this transcript in relationship to the other isoforms.

Of the 3 isoforms identified, NFI-C2 transcripts were the most abundant and NFI-C1 the least abundant, with NFI-C4 levels in between. This was true for all cell types tested (dental and nondental), suggesting the overall pattern of NFI-C splicing is conserved and not tissue specific. However, we did identify 2 dental cell types that showed significant decreases in the levels of the less abundant transcripts NFI-C1 in DF and NFI-C4 in PDL. Interestingly, both of these transcripts contain the $5^{\prime}$ exon 1B. Furthermore, $\mathrm{C} 1$ and $\mathrm{C} 4$ share a common $5^{\prime}$ amino acid $\mathrm{C}$ terminus which differs from that contained in the C2 and C3 isoforms. Since DF and PDL cells are both mesenchymal derived and important in formation of the tooth root structure and its supporting tissues, abnormal levels of these transcripts may have an important role in the root phenotype associated with RDD. However, the biological significance of these transcripts is yet to be established. Further studies are needed to determine their precise role(s) related to cell-specific interactions during root formation.

\section{Acknowledgements}

The authors would like to thank Dr. Isabel Gay for her assistance with these studies. These studies were supported by the Institute of Oral Health Research, University of Alabama at Birmingham, NIH/NIDCR-F30DE018080 (E.L.) and ProDocCAPES (A.C.A.). 


\section{References}

Chaudhry, A.Z., G.E. Lyons, R.M. Gronostajski (1997) Expression patterns of the four nuclear factor I genes during mouse embryogenesis indicate a potential role in development. Dev Dyn 208: 313-325.

das Neves, L., C. Duchala, F. Godinho, M. Haxhiu, C. Colmenares, W. Macklin, C. Campbell, K. Butz, R. Gronostajski (1999) Disruption of the murine nuclear factor I-A gene (Nfia) results in perinatal lethality, hydrocephalus and agenesis of the corpus callosum. Proc Natl Acad Sci USA 96: 11946-11951.

- Gounari, F., R. De Francesco, J. Schmitt, P. van der Vliet, R. Cortese, H. Stunnenberg (1990) Amino-terminal domain of NF1 binds to DNA as a dimer and activates adenovirus DNA replication. EMBO J 9: 559-566.

Grunder A, T.T. Ebel, M. Mallo, G. Schwarzkopf, T. Shimizu, A.E. Sippel, H. Schrewe, (2002) Nuclear factor I-B (Nfib) deficient mice have severe lung hypoplasia. Mech Dev 112: 6977.

Hubbard, T.J.P., B.L. Aken, K. Beal, B. Ballester, M. Caccamo, Y. Chen, L. Clarke, G. Coates, F. Cunningham, T. Cutts, T. Down, S.C. Dyer, S. Fitzgerald, J. Fernandez-Banet, S. Graf, S. Haider, M. Hammond, J. Herrero, R. Holland, K. Howe, N. Johnson, A. Kahari, D. Keefe, F. Kokocinski, E. Kulesha, D. Lawson, I. Longden, C. Melsopp, K. Megy, P. Meid, B. Overduin, A. Parker, A. Prlic, S. Rice, D. Rios, M. Schuster, I. Sealy, J. Severin, G. Slater, D. Smedley, G. Spudich, S. Trevanion, A. Vilella, J. Voge, S. White, M. Wood, T. Cox, V. Curwen, R. Durbin, X.M. FernandezSuarez, P. Flicek, A. Kasprzyk, G. Proctor, S. Searle, J. Smith, A. Ureta-Vidal, E. Birney (2007) Ensembl 2007. Nucleic Acids Res 35: D610-D617.
Kruse, U., A.E. Sippel (1994) The genes for transcription nuclear factor I give rise to corresponding spliced variants between vertebrate species. J Mol Biol 238: $860-$ 865.

MacDougall, M. (1996) Odontoblast cytodifferentiation in monolayer cell cultures: establishment of immortalized odontoblast cell lines; in Shimono, M., T. Maeda, H. Suda, K. Takahashi (eds): Dentin/Pulp Complex Proceedings of the International Conference on Dentin/Pulp Complex 1995 and the International Meeting on Clinical Topics of Dentin/Pulp Complex. Tokyo, Quintessence Publishing Co., pp 116-123.

-Mermod, N., E.A. O’Neill, T.J. Kelly, R. Tjian (1989) The proline-rich transcriptional activator of CTF/NF-I is distinct from the replication and DNA binding domain. Cell 58: 741-753.
Safran, M., V. Chalifa-Caspi, O. Shmueli, T. Olender, M. Lapidot, N. Rosen, M. Shmoish, Y. Peter, G. Glusman, E. Feldmesser, A. Adato, I. Peter, M. Khen, T. Atarot, Y. Groner, D. Lancet (2003) Human Gene-Centric Databases at the Weizmann Institute of Science: GeneCards, UDB, CroW 21 and HORDE. Nucleic Acids Res 31: 142-146.

Santoro, C., N. Mermod, P.C. Andrews, R. Tjian (1988) A family of human CCAAT-boxbinding proteins active in transcription and DNA replication: cloning and expression of multiple cDNAs. Nature 334: 218-224.

-Shmueli, O., D. Horn-Saban, V. Chalifa-Caspi, M. Shmoish, R. Ophir, H. Benjamin-Rodrig, M. Safran, E. Domany, D. Lancet (2003) GeneNote: whole genome expression profiles in normal human tissues. C R Biol 326: 1067-1072.

Steele-Perkins, G., K.G.I. Butz, G.E. Lyons, M. Zeichner-David, H.J. Kim, M.I. Cho, R.M. Gronostajski (2003) Essential role for NFI-C/ CTF transcription-replication factor in tooth development. Mol Cell Biol 23: 1075-1084.

- Yanai, I., H. Benjamin, M. Shmoish, V. ChalifaCaspi, M. Shklar, R. Ophir, A. Bar-Even, S. Horn-Saban, M. Safran, E. Domany, D. Lancet, O. Shmueli (2005) Genome-wide midrange transcription profiles reveal expression level relationships in human tissue specification. Bioinformatics 21: 650-659. 